This is a post-peer-review, pre-copyedit version of an article published in Development. The definitive publisherauthenticated version Coymak, Ahmet and O’Dwyer, Emma (2020) Does Brexit mean a return to sectarianism? Beyond 'the border issue', the future of social identities in Northern Ireland from a political psychological perspective. Development, 63(1), pp. 74-78. is available online at: https://doi.org/10.1057/s41301-019-00233-0 


\title{
Does Brexit Mean a Return to Sectarianism? Beyond 'the Border Issue', the Future of Social Identities in Northern Ireland from a Political Psychological Perspective
}

\author{
Ahmet Çoymak ${ }^{1}$ and Emma O'Dwyer ${ }^{2}$
}

\begin{abstract}
Good Friday Agreement in 1998, appeared to have put an end to the political violence between Catholics and Protestants in Northern Ireland. However, although violence has been reduced after the Good Friday Agreement, the conflict between the two groups, which has deep historical roots, is more likely to be considered a continuous problem on the island. In the Brexit climate where the contested rhetoric of 'sovereignty' is salient, the integrationist process of the GFA may reverse into re-segregation and ancient enmities between denominational groups. Therefore, using both psychological and historical analyses, this article discusses how Brexit affects national identity dynamics in post-conflict Northern Ireland from a political psychological perspective.
\end{abstract}

Keywords Brexit; GFA; Northern Ireland National Identities

'In Northern Ireland, we should have had institutions that respected the differences of the people and that gave no victory to either side', Interview of Nobel Prize for Peace, John Hume 1998

On the 23 June 2016, citizens of four countries of the United Kingdom (UK) - England, Scotland, Wales, and Northern Ireland voted in a referendum on the issue of the UK's membership of the European Union (EU). A majority in Northern Ireland (56\%) and Scotland (62\%) voted to remain in the EU, however 52\% of voters in the UK overall voted to leave. On 29 March 2016, the Prime Minister at the time, Theresa May, triggered Article 50 by writing to European Council President Donald Tusk, formally starting the two-year countdown to the UK's departure. The UK's departure from the EU is widely denoted as 'Brexit', a compound term which joins 'British' and 'exit'. Even this term (Britain as a land-mass refers to England, Scotland, and Wales only) underscores the different experience which the people of Northern Ireland have of the process of leaving the EU. Furthermore, in the historically divided society of Northern Ireland, British is only one national identity among others (Irish, Ulster, and Northern Irish) which is available and claimed by people. Since the signing of the Belfast Agreement in 1998, after 30 years of armed conflict, commonly known as the Good Friday Agreement (GFA), people in Northern Ireland are entitled to have UK or Irish citizenship, or both.

As a consequence of the UK's decision to leave the EU, social and political issues, which were to some extent resolved by the GFA, have re-emerged in the political discourse of post-

\footnotetext{
${ }^{1}$ Barnard College of Columbia University, New York

${ }^{2}$ Kingston University London, London
} 
conflict Northern Ireland. Within the Brexit debate, talk of Northern Ireland has chiefly focused on economic issues and the issue of the border between the Republic of Ireland and Northern Ireland (Soares 2016). However, Brexit also has significant potential to negatively affect the future of peace in this ethno-nationally divided post-conflict society (Gormley-Heenan and Aughey 2017; Stevenson 2017). Indeed, the issue of Brexit represents a new sectarian frontier in Northern Ireland. Analysis of survey data ${ }^{3}$ found that in Northern Ireland the majority of nationalists (88\%) and Catholics (85\%) voted to remain in the EU and the majority of unionists (66\%) and Protestants (60\%) voted to leave. Along with those who described themselves as neither unionist nor nationalist, $70 \%$ voted to stay. Across national identifications, a similar trend was clear, with the majority of those identifying as British (63\%) and Ulster (70\%) voting to leave, and the majority of those identified as Irish preferring to stay (87\%).

From these results, it is clear that Brexit is an issue about identity. Therefore, in this article, we will address the social, political, and historical context of identities in Northern Ireland and evaluate the effect of Brexit on national identities among youth from a political psychological perspective. To do so, we will firstly review historical literature regarding the roots of identity divisions, which ultimately lies at the heart of the conflict between Protestant and Catholic segregation in Northern Ireland. Then, we will focus on the most severe episodes of the conflict between 1968 and 1998, known as 'The Troubles,' and on the social identity dynamics from a psychological perspective. Finally, we will cover the possible outcomes of Brexit on the identity characteristics of young people for the future of Northern Ireland.

\section{The Divided Perspectives on the Historical Roots of the Conflict in Northern Ireland}

The IRA ceasefire in 1994, and later, the GFA in 1998, appeared to have put an end to the political violence between Catholics and Protestants in Northern Ireland. However, although violence has been reduced after the Good Friday Agreement, the conflict between the two groups, which has deep historical roots, is more likely to be considered a continuous problem on the island.

To understand this implacable conflict, divergent disciplines have used different approaches and paradigms and focussed on alternative aspects of the problem. As the segregation between denominational communities has been embedded in the everyday life of people within the social structure, the literature suggests (Whyte 1991; Hennessey 1997; Darby 1998) that there are two different perspectives in defining the historical roots of the current cleavage between Catholics and Protestants. It could hardly be accurate if one draws a direct link between ancient history and the current issues of Northern Ireland. Walker (2007) argues that it is not history which directly affects the current conflict, rather the 'perception of the past, the sense of history or the popular historical narratives, held by individuals and communities, can be a very real factor' (Walker 2007: 103) Therefore, these historical perspectives could be useful tools to analyze the psychology of the society, and how these

\footnotetext{
3 John Garry, The EU referendum Vote in Northern Ireland: Implications for our understanding of citizens' political views and behaviour, Knowledge Exchange Seminar Series (2016-17), Queens University Belfast, https://www.qub.ac.uk/brexit/Brexitfilestore/Filetoupload,728121,en.pdf
} 
psychological effects occur among young generations of Northern Ireland through the impact of Brexit.

The first perspective has a tendency to present the seeds of the conflict as sown in the early 1600 s, when a large group of settlers arrived on the island from across the Irish Sea in Britain. Shortly after that most of the new settlers and $41 \%$ of the entire land, was made up of English and Scottish Protestants who engaged in their own religious, linguistic, and cultural identities and held a majority of the seats in the Irish parliament (Ruane and Todd 1996). According to Terchek (1977), unlike other experiences of British colonialism, the colonizer was faced with a unique problem on the island for two main reasons. The first reason was that the native population of the island was already large and they had to live side by side with this rebellious Irish population. Secondly, French expeditionary forces threatened British security in the region. According to this perspective, the current division between Catholics and Protestants stems from this historical British colonization of Irish soil (Peroff and Hewitt 1980).

This perspective suggests the unique appeal of slogans such as the pro-Brexit 'take back control' mantra, for the people of Northern Ireland. The support of the Democratic Unionist Party (DUP, major Protestant political party in Northern Ireland) for the particularly English project of Brexit can be seen to be rooted in colonial sentiment and debates surrounding sovereignty, themselves key elements of the initial etho-national polarization in Northern Ireland according to this historical perspective. Considering the majority vote for remaining in the EU, the people of Northern Ireland, especially Catholic/Irish and non-denominational people will be forced once-again into a political and economic arrangement, against their will. The results of a 2018 national survey ${ }^{4}$ appear to bear this out, as the priorities of British national identity among Protestants (48.1\%) and Irish national identity among Catholics (79.7\%) were parallel with those reported in 1998; British among Protestant (52.9\%) and Irish among Catholic (71.9\%).

The other historical perspective on the conflict suggests that today's divisions between Catholics and Protestants began in parallel with the human rights movements, which developed from the nineteenth century and spread globally during the 1960s. Heatley (1983) explained that while class distinctions became clear during the early nineteenth century in Northern Ireland, this was not the case for religious differences. The establishment of Belfast's United Irishmen in 1791 was an important milestone in both Belfast and Northern Ireland history. Their activity to support Catholic emancipation led to rebellion, and the hanging of Belfast Protestants led to increasing fears of security and threats among Protestants. In order to protect against this threat, Ulster Protestants established an Orange Order in 1795, especially supported by radical Presbyterian (Heatley 1983).

Today the order is best known with its yearly cultural march, held on 12 July for the celebration of the anniversary of the Battle of the Boyne in 1690. In the beginning of the nineteenth century, Irish nationalism accommodated the entire island. However, while a mass of Catholics supported Irish nationalism; unionized Protestants turned their politics to support home rule and partition, wanting to stay part of the United Kingdom due to increasing autonomy in the island (Terchek 1977; Peroff and Hewitt 1980). As a consequence of an

\footnotetext{
${ }^{4}$ Northern Ireland Young Life \& Times https://www.ark.ac.uk/ylt/quests/ accessed 9 October 2019.
} 
effective guerrilla campaign against British forces, Ireland was partitioned from the United Kingdom in 1922, leaving 26 counties which were predominantly Catholic. However, six northern counties remained a part of the United Kingdom, where the Protestant population engendered the greatest proportion of the population (Peroff and Hewitt 1980).

When we look at the root of the conflict from this perspective in which economical distinction and perceived security threat led eventually to identity cleavage, there is no reason to think otherwise in the case of Brexit. Particularly, that it has created a form of uncertainty which may be perceived as threatening the economic welfare of the people in Northern Ireland. This may be especially the case for the Catholic community because of the DUP's efforts and a means of reasserting the UK's sovereignty. The DUP vision of Brexit in the best interests of Northern Ireland $\square$ encompasses Britain economic investment to replace missing EU funds seems to be limited to those who identify as British, but not Irish. In the event of specific arrangements not being agreed for Northern Ireland, it remains an open question as to the future allocation of these funds for those who claim only Irish citizenship in Northern Ireland, according to the GFA. The rhetoric of Britain 'taking back control' could also be plausibly interpreted as providing reassurance to those anxious about the possibility of future reunification of Northern Ireland and the Republic.

\section{The Troubles: Psychology of Northern Ireland}

Although the origins of conflict and strife among religions can be found in the 300-year past of the island, as mentioned above, 30 years of uninterrupted armed violence are mostly responsible for the current form of conflict between the two groups in Northern Ireland (Hennessey 1997; Darby 1998,). The 1960s represented the first period of recent conflict in Northern Ireland and is generally known as 'The Troubles' due to the level of violence that caused the loss of many lives, as well as to further entrenchment of segregation. This led to clearer divisions between Protestant and Catholic groups in Northern Irish society (O'Leary and McGarry 1993; Hennessey 1997,).

After the partitioning of the island, Protestants dominated the Northern Irish state, which was granted a certain degree of self-government by the British government (Peroff and Hewitt 1980). This British domination led to discrimination against Catholics and forced them into a disadvantaged status in Northern Ireland (Terchek 1977; Peroff and Hewitt 1980). The Northern Irish Civil Rights Association (NICRA) organized a series of protest campaigns in the 1960s. These campaigns were perceived as Republican attacks on the state by many Protestants and began the uninterrupted violence between the Protestant and Catholic communities (Peroff and Hewitt 1980).

In the psychological literature, Northern Ireland has usually been discussed in terms of sectarianism and researchers have tended to focus on the two national and religious groups, Catholics/Nationalist and Protestants/Unionists, to better understand the conflict in Northern Ireland (Trew 2004). However, what it means to be Catholic or Protestant is often related to more than religious or sectarian issues and is also related to political, cultural, and ethnonational identities. Religion should be seen as a boundary marker, where individuals use 
religious identities as an indicator to distinguish between each side of the conflict rather than as a causal factor in the Northern Ireland conflict (O'Connell 1989: 48).

Even though the antagonism between the two communities has been marked as a religious one, the core of the dispute is highly political, with each community having different territorial claims and political leanings and therefore different national identities (Peroff and Hewitt 1980; Bloomfield 1997, Leach and Williams 1999,). The Protestant political view, on the one hand, is that $\mathrm{NI}$ is and should remain an integral part of the UK, a position known as unionism. Most Protestants are expected therefore to define themselves as British. The Catholic political view, on the other hand, is related to nationalism based on a desire to reunite NI with the Republic of Ireland (Peroff and Hewitt 1980; Shirlow and Murtagh 2006). Hence, most Catholics consider themselves to be Irish rather than British or another national identity.

Loyalism and republicanism are concepts used to connote the paramilitary political activities synonymous with the extremism of the Unionist and Nationalist political orientations in Northern Ireland (Brown and MacGinty 2003). Thus, it is the political or national ideologies, rather than the Protestant and Catholic religious discourses per se, that are used to define the border between the two. However, Ferguson and Gordon's (2007) study with 223 Catholic and Protestant individuals showed that there is variability within both Protestant and Catholic groups in terms of their political views. They found a non-significant relationship between religious affiliation and certain political statements such as political solutions of Northern Ireland (e.g., 'should stay as a part of UK').

\section{National Identity Dynamics and the Ongoing Situation in Northern Ireland}

There seems to be consensus regarding the factors responsible for the conflict between research disciplines such as historical, religious, political, economic, and psychological sciences (Whyte 1991; Bloomfield 1997; Darby 1998). The current literature about the Northern Ireland conflict emphasizes the importance of psychological factors, especially since the end of the overt political violence in the 1990s (Cairns and Darby 1998). However, the issues which have re-emerged throughout the Brexit process further underscore the necessity of psychological explanations in order to better understand and predict the future of peace in Northern Ireland.

Over the years, psychologists have applied a number of theories to understand the conflict and its underlying psychological complexities. Social Identity Theory (SIT) is the most prominent psychological theory used in this endeavour. In contrast to the theoretical and analytical shortcomings of the initial psychological explanations of the Northern Irish conflict, which tended to interpret conflict at an interpersonal level and ignore the role of history, culture, economics and politics, SIT provides a useful starting point for explaining conflict in the context of an intergroup process (Cairns and Darby 1998). According to the theory, the term 'social identity' means that when individuals belong to certain groups, group membership becomes internalized as their self-concept. Therefore, people have a tendency to see themselves and others via group memberships. According to SIT, people want to maintain a positive social identity, which in turn leads to positive self-evaluation via their group membership (Tajfel and Turner 1986). Therefore, when they perceive a threat from an out- 
group, they engage in adaptive strategies (e.g., increase their identification) to overcome this threat.

Although this theory fits well into understandings of the psychological dynamics of the conflict in Northern Ireland since the 1960s, recent approaches have criticized some important issues as shortcomings of SIT. For instance, one of the critiques is that the theory overemphasizes the general processes of social categorization and social comparison, disregarding the significant ideological differences associated with political subgroups in a particular context such as Northern Ireland (Gough et al. 1992). Another criticism is that SIT theorists have seen social identities as one particular self-component composed of the global self rather than individuals' overall self-concept being conceived as the complex interrelationship of multiple identities (Deaux 1991; Brewer 1999; Amiot et al. 2007). It has been suggested that neglecting such multiple identities oversimplifies the context and situation specific nature of social identities, attitudes and behaviours and thereby cannot capture and explain intergroup relations in the post-conflict societies. However, recent psychological studies advanced these shortcomings by taking more complex models and multiple social identities into account in the context of post-conflict Northern Ireland.

For instance, re-categorizing antagonistic group identity into a common identity is one of the high levels of achievement in reconciliation between post-conflict group and its core principles at the root of peace processes in post-conflict communities, where social transition takes place with radical change. These changes were the case in Northern Ireland's peace process, starting with the Good Friday Agreement. A study from a social identity perspective, conducted with a large national survey among young people in 2010 showed that, especially since 2003, a newly emerged common national identity, Northern Irish identity, has been prioritized among young people. However, this trend occurs for only young Protestant people but not for Catholic youth. Furthermore, more nuanced models, which allow participants to freely choose and evaluate multiple national identities, clarified this one-side trend by showing that the Northern Irish identity has a positive effect on trust in other community members for both Catholic and Protestant youths in Northern Ireland while the traditional British and Irish national identity still has a significant negative effect on inter-community relations among young people (Çoymak 2015: 156).

This positive effect of Northern Irish identity on trust in other community members occurs through political trust, which suggests that the transformation of political institutions via a power-sharing system between the two communities, brought about by the GFA, has paid off in some sense. The meanings of Northern Irish identity for the young people are Northern Ireland are varied (Garry and McNicholl 2019; Trew 1994). However, the social identity content model also shows the positive effect of Northern Irish identity though political trust in other community politicians is dependent on the extent to which an individual conceptualizes Northern Irish identity as civic instead of essentialist. Therefore, the newly-emerged Northern Irish common national identity in post-conflict context has a strong potential to contribute a sustainable peace, which can also be conceptualized as the identity under construction in the current context of Northern Ireland. Yet, in the Brexit climate where the contested rhetoric of 'sovereignty' is salient, it is possible to hypothesize that the integrationist process of GFA, at least for the young generations may reverse into re-segregation and ancient enmities between denominational groups. This is evident from our recent study with a large national survey in 
2016 (Çoymak and O'Dwyer forthcoming), which showed that Brexit was one of the most significant factors among various alternatives, including 30 factors related to ethno-national characteristics and intergroup relations, was related to the choice of either traditional ethnonational identities (Irish/British) or the newly-emerged common identity (Northern Irish).

\section{Identity Characteristics, Brexit, and the Future of the GFA in Northern Ireland}

To sum up, through the historical division between the two denominational groups, focusing on religious affiliation is insubstantial to understand the intergroup conflict in Northern Ireland. As a psychological process, individuals' identification with a structured collective group united by a common belief and opinion about 'us' and 'them', beyond the obvious yet misleading theological affiliation, provides a more comprehensive explanation of the conflict. In the current climate of Brexit, the opportunity to build a meaningful common identity for a historically divided society may be missing once again. The evidence of increasing segregation for the preference of national identities among youths suggests that if Northern Ireland does not want to upset the delicate balance for the future of peace between Catholic and Protestant communities, any decisions must encompass 'institutions that respect the differences of the people and that gave no victory to either side' in Northern Ireland.

\section{References}

Amiot, Catherine E., Roxane De la Sablonniere, Deborah J. Terry and Joanne R. Smith. 2007. Integration of social identities in the self: Toward a cognitive-developmental model. Personality and Social Psychology Review 11(4): 364-388.

Bloomfield, David. 1997. Peacemaking strategies in Northern Ireland: Building complementarity in conflict management theory. Springer.

Brewer, Marilynn B. 1999. The psychology of prejudice: Ingroup love and outgroup hate?. Journal of social issues, 55(3): 429-444.

Brown, Kris and Roger MacGinty. 2003. Public attitudes toward partisan and neutral symbols in post-agreement Northern Ireland. Identities: Global studies in culture and power 10(1): 83-108.

Cairns, Ed and John Darby. 1998. The conflict in Northern Ireland: Causes, consequences, and controls. American psychologist 53(7): 754.

Çoymak, Ahmet and O'Dwyer, Emma. Forthcoming. The future of the peace in Northern Ireland: The multifaceted nature of Good Friday Agreement and Brexit.

Çoymak, Ahmet. "The dynamics of citizenship, multiple identities and intergroup trust amongst young people in Northern Ireland." PhD diss., Queen's University Belfast, 2015.

Darby, John. 1998. Approaches to cultural diversity in Northern Ireland. in Cultural Traditions in Northern Ireland, Maurna Crozier and Richard Froggatt (eds.) Belfast: Institute of Irish Studies: 3-12. 
Deaux, Kay. 1991. Social identities: Thoughts on structure and change. The relational self: Theoretical convergences in psychoanalysis and social psychology 77: 93.

Hume, John. 1998. Nobel Lecture. NobelPrize.org. Nobel Media AB 2019. Tue. 12 Nov 2019. <https://www.nobelprize.org/prizes/peace/1998/hume/lecture/>

Ferguson, Neil and Michael Gordon. 2007 Intragroup variability among Northern Irish catholics and protestants. The Journal of social psychology 147(3): 317-319.

Garry, John and Kevin McNicholl. 2015- Understanding the 'Northern Irish'Identity. In Briefing Paper presented at the Knowledge Exchange Seminar Series (KESS).

Gormley-Heenan, Cathy and Arthur Aughey. 2017. Northern Ireland and Brexit: Three effects on 'the border in the mind'. The British Journal of Politics and International Relations 19(3): 497-511.

Gough, Brendan, Stephen Robinson, John Kremer and Rex Mitchell. 1992. The social psychology of intergroup conflict: An appraisal of Northern Ireland research. Canadian Psychology/Psychologie canadienne 33(3): 645.

Heatley. Fred. 1983. Community Relations and the Religious Demography 1800-86, in J. C. Beckett et al., Belfast: The Making of the City 1800-1914 (Belfast): Appletree Press 12934.

Hennessey, Thomas. 1997. A history of Northern Ireland, 1920-1996. Basingstoke: Macmillan. Leach, Colin Wayne and Wendy R. Williams. 1999. Group identity and conflicting expectations of the future in Northern Ireland. Political Psychology 20(4), 875-896.

O'Connell, James. 1989. Faith and Conflict: Religion and Politics in Northern Ireland. School of Peace Studies, University of Bradford.

O'Leary, Brendan and John McGarry. 1993. The politics of Antagonism: Understanding Northern Ireland, Auditing the antagonism: 8-44.

Peroff, Kathleen and Christopher Hewitt. 1980. Rioting in Northern Ireland: The effects of different policies. Journal of Conflict Resolution 24(40): 593-612.

Ruane, Joseph and Jennifer Todd. 1996. The dynamics of conflict in Northern Ireland: Power, conflict and emancipation. Cambridge University Press.

Shirlow, Peter and Brendan Murtagh. 2006. Belfast: Segregation, violence and the city. Pluto Press.

Soares, Anthony. 2016. Living within and outside unions: The consequences of Brexit for Northern Ireland, Journal of Contemporary European Research 12(4).

Stevenson, Jonathan. "Does Brexit Threaten Peace in Northern Ireland?." Survival 59, no. 3 (2017): 111-128.

Tajfel, Henri and John C. Turner. 1986. The Social Identity Theory of Intergroup Behavior. Psychology of intergroup relations 5: 7-24.

Terchek, Ronald J. 1977. Conflict and cleavage in Northern Ireland. The ANNALS of the American Academy of Political and Social Science 433(1): 47-59.

Trew, Karen. 2004. Children and socio-cultural divisions in Northern Ireland. Journal of Social Issues,60(3): 507-522.

Walker, Brian M. 2007. "Ancient Enmities" and Modern Conflict: History and Politics in Northern Ireland. Nationalism and Ethnic Politics 13(1): 103-128.

Whyte, J. 1991. Interpreting Northern Ireland. Clarendon Press. 